\title{
Heavy metals in water, sediments and plants of the Zegrzyński Lake
}

\author{
Metale ciężkie w wodzie, osadach i roślinach Jeziora Zegrzyńskiego
}

\author{
Małgorzata Wojtkowska
}

\section{Summary}

In the years 1998-2000 the studies were carried out on water, bottom sediments and plant materials collected from the Zegrzyński Lake. Metals ( $\mathrm{Zn}, \mathrm{Cu}, \mathrm{Pb}$, and $\mathrm{Cd}$ ) were detected in water, in dissolved fractions (hydrated ions, labile and inert complexes), suspended matter and in bottom sediments. The samples of plant parts (roots, stalks and leaves) and molluscs were also analysed. The obtained results showed the best activity (nearly 90\%) in metals' binding registered in suspended matter. A strong power in metals' binding was shown by molluscs occurring on the bottom of the water reservoir. Taking into consideration plant part, the highest concentration of $\mathrm{Zn}$ and $\mathrm{Pb}$ were detected in roots and $\mathrm{Cu}$ in green parts. The concentration of $\mathrm{Zn}$ and $\mathrm{Pb}$ were higher in molluscs than in the sediments and roots. Also the concentration of $\mathrm{Cd}$ was higher in molluscs than in the bottom sediments and parts of plant parts.

Key words: metals; surface water; sediments; plant; speciation

\section{Streszczenie}

W latach 1998-2000 wykonano badania: wody, osadów dennych i roślinności, pobranych z Jeziora Zegrzyńskiego. Metale (Zn, Cu, $\mathrm{Pb}$ i $\mathrm{Cd}$ ) oznaczono $\mathrm{w}$ toni wodnej we frakcji rozpuszczonej (hydratowane jony i labilne kompleksy oraz inertne kompleksy) i zawiesinowej oraz w osadach dennych. Do badań pobrano również próbki roślin i mięczaków. Próbki roślin podzielono na części korzeniowe, łodygi i zielone. Przeprowadzone badania wykazały, że najwyższą aktywność w wiązaniu metali wykazywały zawiesiny (ponad 90\%). Rozdział metali w osadach dennych był podobny do rozkładu we frakcji zawiesinowej. Dużą siłę wiązania metali stwierdzono dla mięczaków zdeponowanych na dnie zbiornika. W częściach roślin najwyższe stężenia Zn i Pb stwierdzono dla korzeni, natomiast $\mathrm{Cu}$ dla części zielonych. Stężenie $\mathrm{Zn}$ i Pb w muszlach było wyższe niż w osadach i korzeniach. Również stężenie Cd było wyższe w muszlach niż w osadach dennych i częściach roślin.

Słowa kluczowe: metale; woda powierzchniowa; osady; rośliny; specjacja

\footnotetext{
Politechnika Warszawska

Wydział Inżynierii Środowiska

Nowowiejska 20, 00-653 Warszawa

malgorzata.wojtkowska@is.pw.edu.p
} 


\section{Wstęp / Introduction}

W ostatnich latach stwierdza się, że toksyczność i bioprzyswajalność metali ciężkich zależy bardziej od form chemicznych, w jakich występują niż od ich całkowitego stężenia. Metale ciężkie moga występować w wodzie w postaci rozpuszczonej, koloidalnej i zawiesinowej. Jony metali można podzielić na dwie grupy: mające tendencję do występowania w roztworze (np. jony sodu i potasu) lub w zawiesinie (np. jony miedzi mają tendencję do adsorpcji na cząstkach zawiesin).

W wodach naturalnych metale występują w postaci: hydratowanych wolnych jonów, nieorganicznych i organicznych kompleksów oraz par jonowych. Mogą być związane z wielkocząsteczkowymi substancjami organicznymi, w formie zdyspergowanych koloidów lub zaadsorbowane na cząstkach innych koloidów oraz w osadach dennych. Formy kompleksowe metali dominują w wodach, w których ligandy organiczne i nieorganiczne występują w dużych stężeniach (Steinberg 1980). Postać, w jakiej występują metale ciężkie w wodach powierzchniowych ma szczególne znaczenie z punktu widzenia ich toksycznego działania na organizmy żywe. Całkowitą zawartość metalu w wodzie można podzielić na dwie zasadnicze frakcje: zawiesinową i rozpuszczoną (hydratowane jony, labilne i inertne kompleksy), które można w prosty sposób rozdzielić sącząc na sączkach membranowych (Wojtkowska 2000). Forma metalu zależy od jego właściwości, rozpuszczalności w wodzie, zdolności do adsorpcji na cząstkach stałych, zdolności do tworzenia kompleksów, od temperatury, $\mathrm{pH}$ i $\mathrm{pE}$, siły jonowej oraz składu chemicznego wody. Większość metali w wodzie nie utrzymuje się długo w formie rozpuszczonej, lecz ulegają licznym procesom prowadzącym do deponowania ich w osadach dennych, z których mogą być uwalniane i transportowane na duże odległości. Do oceny zanieczyszczenia wód metalami często stosuje się metodę pośrednią, polegającą na analizie zawartości ich w osadach dennych. Formy wiązania metali ciężkich w osadach dennych zależą od warunków środowiska wodnego, od struktury i składu chemicznego osadów (Głosińska i Siepak 2006). Jeżeli w warstwie naddennej wody panują warunki aerobowe, $\mathrm{w}$ osadach przeważają mobilne formy związane $\mathrm{z}$ węglanami oraz uwodnionymi tlenkami żelaza i manganu. W warunkach silnie anaerobowych (redukcyjnych), występują głównie trwałe formy metali związane w postaci połączeń organiczno-siarczkowych i glinokrzemianowych. Metale zdeponowane $\mathrm{w}$ osadach pozostają $\mathrm{w}$ równowadze dynamicznej z fazą wodną (Helios-Rybicka 1991; Wojtkowska 2011). Z tych faz mogą przenikać do organizmów zasiedlających zbiornik wodny. Wiązanie metali przez roślinność wodną może zachodzić przez części zielone (nadwodne i czesściowo zanurzone) oraz przez system korzeniowy. Przyjmuje się, że stopień przyswajalności metali przez rośliny zależy przede wszystkim od stężenia hydratowanych jonów i labilnych kompleksów występujących $\mathrm{w}$ toni wodnej oraz stężenia metalu zawartego w labilnych frakcjach (jonowymiennej i węglanowej) osadów dennych.
Celem prowadzonych badań było określenie stężeń form metali ciężkich $\mathrm{w}$ toni wodnej, w osadach i w biomasie występującej w Jeziorze Zegrzyńskim.

\section{Materiały i metody / Materials and methods}

Badanie występowania metali ciężkich w Jeziorze Zegrzyńskim przeprowadzono $\mathrm{w}$ próbkach wody, osadów dennych, mięczaków i roślin wodnych, pobranych na dopływie wody rzeki Narew (trzy stanowiska) i w części zastoiskowej na odpływie wody w okolicy zapory w Dębe (trzy stanowiska) (rys. 1). Próbki wody pobierano czerpakiem Ruttnera z dwóch głębokości - warstwy powierzchniowej (do 0,5 m) i naddennej (0,5 m nad dnem). Próbki wierzchniej warstwy osadów dennych $(10 \mathrm{~cm})$ pobrano próbnikiem Kajaka. Z osadów dennych oddzielono próbki mięczaków z gatunku małż szczeżuja pospolita (Anodonta anatina). Nabrzeże Jeziora Zegrzyńskiego porośnięte jest $\mathrm{w}$ różnym stopniu roślinnością wodną i bagienną. Można w nich wyróżnić: zbiorowiska szuwarowe ze skrzypem bagiennym (Equisetum fluviatile) i oczeretem jeziornym (Schoenoplectus lacustris), szuwary manny jadalnej (Glyceria fluitans), pałki wąskolistnej (Typha angustifolia) i szerokolistnej (Typha latifolia), a także jeżogłówki gałęzistej (Sparganium erectum) (Kamiński 2011). Do badań pobrano próbki oczeretu jeziornego (nazywanego sitowiem), z obszarów nadbrzeżnych usytuowanych $\mathrm{w}$ okolicy stanowisk poboru wody i osadów dennych. Poboru próbek dokonywano czterokrotnie w roku, w okresie od maja do września. Łącznie pobrano próbek: 96 wody, 48 osadów, roślinności i małż.

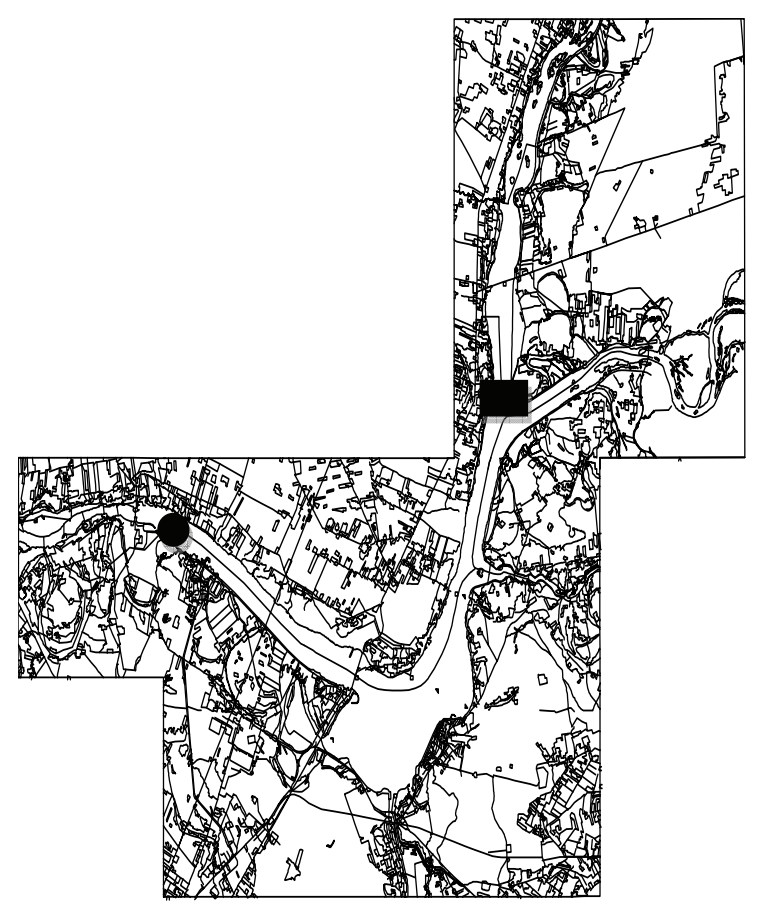

Rys. 1. Stanowiska pomiarowe na Zbiorniku Zegrzyńskim Fig. 1. Location of sampling points in the Zegrzyński reservoir 
Po dostarczeniu do laboratorium, próbki wody filtrowano przez sączki membranowe o średnicy porów $0,45 \mu \mathrm{m}$ (Synpor, Czechosłowacja). W wodzie po filtracji oznaczono hydratowane jony i labilne kompleksy metali (po wcześniejszym zakwaszeniu) stosując metodę różnicowej pulsowej woltamperometrii inwersyjnej DPASV (Differential Pulse Anodic Stripping Voltammetry), a metale związane w inertne kompleksy metodą woltoamperometriczną ASV (Anodic Stripping Voltammetry), po przefiltrowaniu próbek wody i mineralizacji metodą fotoutleniania. Zawiesinę pozostałą na sączku oraz próbki osadów dennych po wysuszeniu $\mathrm{w}$ temperaturze pokojowej mineralizowano mieszaniną stężonych kwasów $\mathrm{HNO}_{3} / \mathrm{HClO}_{4}$. Mineralizację prowadzono $\mathrm{w}$ naczyniach teflonowych umieszczonych $\mathrm{w}$ bloku do mineralizacji. Po mineralizacji roztwór sączono do kolb miarowych o pojemności $100 \mathrm{~cm}^{3}$, uzupełniając wodą destylowaną do kreski. Próbki roślinności podzielono na część: nadwodną (zieloną), łodygową i korzeniową. Wysuszone próbki roślin i mięczaków (muszli) mineralizowano podobnie, jak osady i zawiesinę. W otrzymanych roztworach zawartość $\mathrm{Zn}, \mathrm{Cu}, \mathrm{Pb}$ i $\mathrm{Cd}$ oznaczono metodą absorpcyjnej spektrometrii atomowej $\mathrm{z}$ atomizacją płomieniową F-AAS (Flame Atomic Absorption Spektrometry).

\section{Wyniki i dyskusja / Results and discussion}

Zawartość całkowitych stężeń rozpuszczonych form miedzi, cynku, ołowiu i kadmu w dwóch warstwach wody (powierzchniowej i naddennej) kształtowała się w sposób zróżnicowany (tab. 1, rys. 2). Spośród badanych metali najniższe stężenia $\mathrm{w}$ wodzie wykazywał kadm (średnio $9 \mu \mathrm{g} / \mathrm{l}-\mathrm{w}$ powierzchniowej i $16 \mu \mathrm{g} / \mathrm{l} \mathrm{w}$ dolnej warstwie). Miedź występowała w wyższych stężeniach w obydwu warstwach (odpowiednio 18 i $27 \mu \mathrm{g} / \mathrm{l}$ ). Najwyższe stężenia, w powierzchniowej i dolnej warstwie, wykazywał cynk (33 i $50 \mu \mathrm{g} / \mathrm{l}$ ) oraz ołów (55 i $76 \mu \mathrm{g} / \mathrm{l}$ ). Stężenia dla $\mathrm{Zn} \mathrm{i} \mathrm{Cu} \mathrm{występowały} \mathrm{w} \mathrm{zakresie} \mathrm{dopuszczalnych} \mathrm{wartości}$ (odpowiednio 1,0 i 0,05 mg/l) dla wskaźników jakości wód z grupy substancji szczególnie szkodliwych dla środowiska wodnego (specyficzne zanieczyszczenia syntetyczne i niesyntetyczne) odnoszące się do dobrego i wyższego niż dobry stanu ekologicznego jednolitych części wód powierzchniowych (Rozporządzenie Ministra Środowiska z dnia 9 listopada 2011 r. w sprawie sposobu klasyfikacji jednolitych części wód powierzchniowych, Dz. U. $2011 \mathrm{r}$. nr 257 poz. 1545). Wartości ołowiu i kadmu przekraczały dopuszczalne stężenia przewidziane tym Rozporządzeniem (dla $\mathrm{Pb}$ wartość stężenia średniorocznego 7,2 $\mu \mathrm{g} / 1$, a dla $\mathrm{Cd}$ maksymalne dopuszczalne stężenie 1,5 $\mu \mathrm{g} / \mathrm{l})$.

Stężenia metali związane $\mathrm{z}$ zawiesiną zestawiono $\mathrm{w}$ tabeli 2. Jak wynika $\mathrm{z}$ badań, ilości metali unieruchomione w zawiesinie stanowią ponad 90\% całkowitej zawartości metali w wodzie. W obydwu warstwach wody (powierzchniowej i naddennej) najsilniej wiązany w zawiesinie był cynk (średnio około 6,5 i 7,5 mg/l w poszczególnych warstwach wody) i ołów (średnio około 3,5 i 4,0 mg/l w poszczególnych warstwach wody). Dwa pozostałe metale $(\mathrm{Cu}$ i $\mathrm{Cd})$ występowały w zawiesinie w mniejszych stężeniach $(\mathrm{Cu}$ średnio około 0,4 i $1,0 \mathrm{mg} / \mathrm{l}$, a Cd średnio około $0,7 \mathrm{mg} / \mathrm{l} \mathrm{w}$ obu warstwach wody) (rys. 3). Uzyskane wyniki wskazują na istotną rolę zawiesiny w transporcie metali ciężkich (Barbusiński i wsp. 2012).

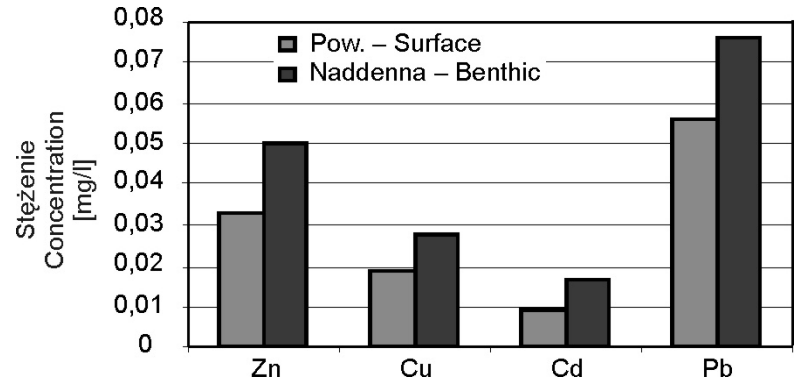

Rys. 2. Metale ciężkie w fazie wodnej - wartości średnie w powierzchniowej i naddennej warstwie wody

Fig. 2. Heavy metals in water phase - mean values in surface and benthic water layer

Tabela 1. Stężenia rozpuszczonych form metali ciężkich w warstwie powierzchniowej i naddennej wody [ $\mu \mathrm{g} / 1]$ oraz statystyka opisowa Table 1. Concentrations of dissolved forms of heavy metals in the surface and benthic layer of water $[\mu \mathrm{g} / 1]$ and descriptive statistics

\begin{tabular}{|c|c|c|c|c|c|c|c|c|}
\hline \multirow{3}{*}{ Stanowiska - Position } & \multicolumn{2}{|c|}{$\mathrm{Zn}$} & \multicolumn{2}{|c|}{$\mathrm{Cu}$} & \multicolumn{2}{|c|}{$\mathrm{Cd}$} & \multicolumn{2}{|c|}{$\mathrm{Pb}$} \\
\hline & \multicolumn{8}{|c|}{ rodzaj warstwy - type of layer } \\
\hline & $\begin{array}{c}\text { powierz. } \\
\text { surface }\end{array}$ & $\begin{array}{l}\text { naddenna } \\
\text { benthic }\end{array}$ & $\begin{array}{c}\text { powierz. } \\
\text { surface }\end{array}$ & $\begin{array}{l}\text { naddenna } \\
\text { benthic }\end{array}$ & $\begin{array}{c}\text { powierz. } \\
\text { surface }\end{array}$ & $\begin{array}{l}\text { naddenna } \\
\text { benthic }\end{array}$ & $\begin{array}{l}\text { powierz. } \\
\text { surface }\end{array}$ & $\begin{array}{c}\text { naddenna } \\
\text { benthic }\end{array}$ \\
\hline 1 & 39,4 & 22,5 & 17,3 & 42,4 & 3,0 & 3,6 & 11,0 & 29,4 \\
\hline 2 & 29,5 & 37,5 & 9,4 & 27,0 & 0,3 & 3,7 & 3,9 & 32,3 \\
\hline 3 & 50,8 & 56,9 & 13,6 & 16,2 & 13,5 & 14,7 & 220,3 & 250,0 \\
\hline 4 & 31,4 & 47,6 & 19,2 & 20,9 & 15,3 & 37,0 & 27,0 & 43,0 \\
\hline 5 & 25,5 & 29,6 & 41,5 & 30,3 & 12,8 & 13,5 & 30,2 & 47,6 \\
\hline 6 & 22,8 & 108,4 & 11,9 & 26,3 & 11,4 & 27,6 & 43,2 & 54,8 \\
\hline \multicolumn{9}{|c|}{ Statystyka opisowa - Descriptive statistics } \\
\hline Średnia-Mean & 33,2 & 50,4 & 18,8 & 27,2 & 9,4 & 16,7 & 55,9 & 76,2 \\
\hline Mediana-Median & 30,5 & 42,6 & 15,5 & 26,7 & 12,1 & 14,1 & 28,6 & 45,3 \\
\hline Min & 22,8 & 22,5 & 9,4 & 16,2 & 0,3 & 3,6 & 3,9 & 29,4 \\
\hline Max & 50,8 & 108,4 & 41,5 & 42,4 & 15,3 & 37,0 & 220,3 & 250,0 \\
\hline
\end{tabular}


Tabela 2. Stężenia zawiesinowych form metali ciężkich w warstwie powierzchniowej i naddennej wody [mg/l] oraz statystyka opisowa

Table 2. The concentrations of suspension form of heavy metals in the surface and benthic layer of water [mg/l] and descriptive statistics

\begin{tabular}{|c|c|c|c|c|c|c|c|c|}
\hline \multirow{3}{*}{ Stanowiska - Position } & \multicolumn{2}{|c|}{$\mathrm{Zn}$} & \multicolumn{2}{|c|}{$\mathrm{Cu}$} & \multicolumn{2}{|c|}{$\mathrm{Cd}$} & \multicolumn{2}{|c|}{$\mathrm{Pb}$} \\
\hline & \multicolumn{8}{|c|}{ rodzaj warstwy - type of layer } \\
\hline & $\begin{array}{c}\text { powierz. } \\
\text { surface }\end{array}$ & $\begin{array}{l}\text { naddenna } \\
\text { benthic }\end{array}$ & $\begin{array}{c}\text { powierz. } \\
\text { surface }\end{array}$ & $\begin{array}{c}\text { naddenna } \\
\text { benthic }\end{array}$ & $\begin{array}{c}\text { powierz. } \\
\text { surface }\end{array}$ & $\begin{array}{l}\text { naddenna } \\
\text { benthic }\end{array}$ & $\begin{array}{c}\text { powierz. } \\
\text { surface }\end{array}$ & $\begin{array}{c}\text { naddenna } \\
\text { benthic }\end{array}$ \\
\hline 1 & 5,153 & 5,413 & 1,216 & 2,415 & 1,156 & 0,490 & 0,995 & 1,125 \\
\hline 2 & 3,965 & 3,368 & 0,271 & 0,508 & 1,323 & 1,199 & 7,263 & 6,630 \\
\hline 3 & 7,039 & 6,716 & 0,076 & 0,101 & 0,680 & 0,926 & 5,861 & 6,973 \\
\hline 4 & 15,800 & 16,233 & 0,416 & 0,760 & 0,597 & 0,723 & 4,012 & 4,019 \\
\hline 5 & 3,215 & 6,076 & 0,187 & 1,180 & 0,251 & 0,490 & 1,426 & 2,356 \\
\hline 6 & 3,698 & 6,987 & 0,215 & 1,357 & 0,289 & 0,564 & 1,640 & 2,710 \\
\hline \multicolumn{9}{|c|}{ Statystyka opisowa - Descriptive statistics } \\
\hline Średnia - Mean & 6,48 & 7,47 & 0,40 & 1,05 & 0,72 & 0,73 & 3,53 & 3,97 \\
\hline Mediana-Median & 5,15 & 6,72 & 0,27 & 1,05 & 0,68 & 0,72 & 3,53 & 3,97 \\
\hline Min & 3,22 & 3,37 & 0,08 & 0,10 & 0,25 & 0,49 & 1,00 & 1,13 \\
\hline Max & 15,80 & 16,23 & 1,22 & 2,42 & 1,32 & 1,20 & 7,26 & 6,97 \\
\hline
\end{tabular}

Tabela 3. Aktywne i inertne formy metali w wodzie Jeziora Zegrzyńskiego $[\mu \mathrm{g} / 1]$

Table 3. Forms of active and inert metals in water of Zegrzyński Lake $[\mu \mathrm{g} / 1]$

\begin{tabular}{c|c|c|c|c|c|c|c}
\hline \multicolumn{2}{c|}{ Zn } & \multicolumn{2}{c|}{$\mathrm{Pb}$} & \multicolumn{2}{c}{$\mathrm{Cd}$} & \multicolumn{2}{c}{$\mathrm{Cu}$} \\
\hline $\mathrm{J}+\mathrm{LK}$ & $\mathrm{IK}$ & $\mathrm{J}+\mathrm{LK}$ & $\mathrm{IK}$ & $\mathrm{J}+\mathrm{LK}$ & $\mathrm{IK}$ & $\mathrm{J}+\mathrm{LK}$ & $\mathrm{IK}$ \\
\hline 196,0 & 199,0 & 2,3 & 5,9 & 3,70 & 4,10 & 1,74 & 2,64 \\
\hline 52,0 & 66,1 & 4,9 & 9,8 & 3,03 & 3,93 & 2,12 & 3,32 \\
\hline 47,3 & 62,0 & 8,7 & 17,6 & 0,74 & 1,01 & 2,44 & 3,44 \\
\hline 113,1 & 137,3 & 9,0 & 10,9 & 1,04 & 1,27 & 4,83 & 5,56 \\
\hline 52,5 & 54,8 & 4,7 & 9,7 & 0,55 & 0,72 & 3,60 & 4,01 \\
\hline 34,8 & 37,4 & 8,9 & 13,7 & 1,26 & 1,25 & 3,48 & 5,50 \\
\hline
\end{tabular}

Tabela 4. Stężenia metali w osadach dennych [mg/kg s.m.] oraz średnia i mediana

Table 4. Concentrations of heavy metals in sediments $[\mathrm{mg} / \mathrm{kg}$ d.m.] and the mean and median

\begin{tabular}{c|c|c|c|c}
\hline $\begin{array}{c}\text { Stanowiska } \\
\text { Position }\end{array}$ & $\mathrm{Zn}$ & $\mathrm{Cu}$ & $\mathrm{Pb}$ & $\mathrm{Cd}$ \\
\hline 1 & 72,5 & 61,4 & 34,8 & 5,4 \\
\hline 2 & 73,7 & 35,4 & 31,3 & 5,3 \\
\hline 3 & 66,8 & 31,1 & 35,6 & 12,5 \\
\hline 4 & 78,7 & 51,9 & 43,2 & 12,4 \\
\hline 5 & 52,9 & 34,8 & 29,2 & 18,3 \\
\hline 6 & 92,9 & 83,6 & 62,5 & 14,3 \\
\hline Średnia-Mean & 72,9 & 49,7 & 39,4 & 11,4 \\
\hline $\begin{array}{l}\text { Mediana } \\
\text { Median }\end{array}$ & 73,1 & 43,6 & 35,2 & 12,4 \\
\hline
\end{tabular}

Metale w wodzie ulegają wiązaniu przez substancje organiczne, dlatego często ich postać to proste organiczne kompleksy oraz wielkocząsteczkowe substancje organiczne. Mogą też występować w postaci zaabsorbowanej na cząstkach koloidów. Rozpuszczone w wodzie związki

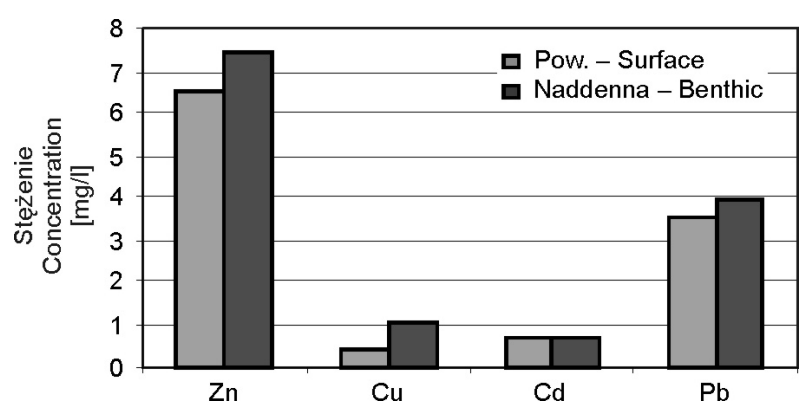

Rys. 3. Metale ciężkie w zawiesinie - wartości średnie w powierzchniowej i naddennej warstwie wody

Fig. 3. Heavy metals in suspension phase - mean values in surface and benthic water layer

organiczne (substancje humusowe - $\mathrm{SH}$ ) stanowią istotny dla biogeochemii metali makroskładnik wód powierzchniowych. Zawierają one aktywne chemicznie podstawniki, tworzace $\mathrm{z}$ metalami rozpuszczalne inertne kompleksy (IK) (Fang i wsp. 2005), zwiększając ich stężenie w wodzie, jednocześnie zmniejszając stężenie toksycznych nieorganicznych form metali, do których należą hydratowane 
jony i labilne kompleksy ( $\mathrm{J}+\mathrm{LK})$. Rozdział aktywnych $(\mathrm{J}+\mathrm{LK})$ i inertnych (IK) form metali wykazał równomierny ich udział $\mathrm{w}$ ogólnej zawartości obecnych w toni wodnej rozpuszczonych metali (tab. 3).

Tabela 5. Udział metali w częściach roślin, mięczakach oraz osadach dennych $[\mathrm{mg} / \mathrm{kg}$ s.m.]

Table 5. Participation of metals in parts of plants, molluses and sediments [mg/kg d.m.]

\begin{tabular}{l|c|c|c|c}
\hline & $\mathrm{Zn}$ & $\mathrm{Pb}$ & $\mathrm{Cd}$ & $\mathrm{Cu}$ \\
\hline Trawa - Grass & 77,80 & 11,20 & 1,48 & 46,79 \\
\hline Lodygi - Stems & 14,65 & 10,91 & 0,51 & 1,25 \\
\hline Korzenie - Roots & 33,49 & 55,76 & 0,28 & 13,35 \\
\hline Muszle - Mollusc & 76,34 & 75,42 & 5,20 & 9,21 \\
\hline Osad - Sediments & 34,01 & 73,36 & 1,28 & 15,61 \\
\hline
\end{tabular}

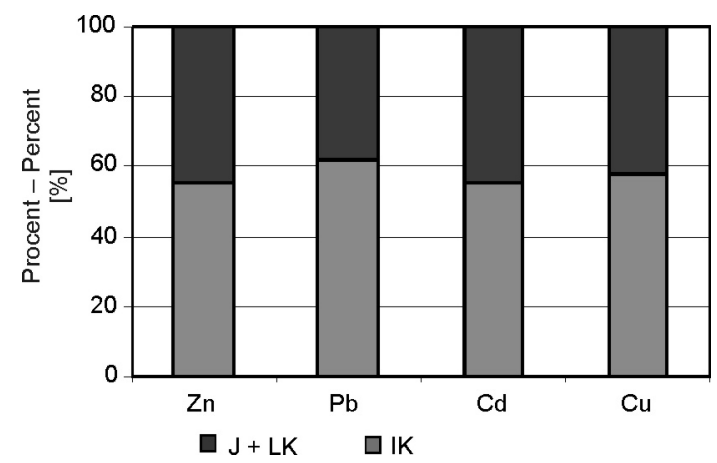

Rys. 4. Udział procentowy ( + LK) i IK metali ciężkich w wodzie

Fig. 4. Participation proportional $(\mathrm{J}+\mathrm{LK})$ and IK of heavy metals in water

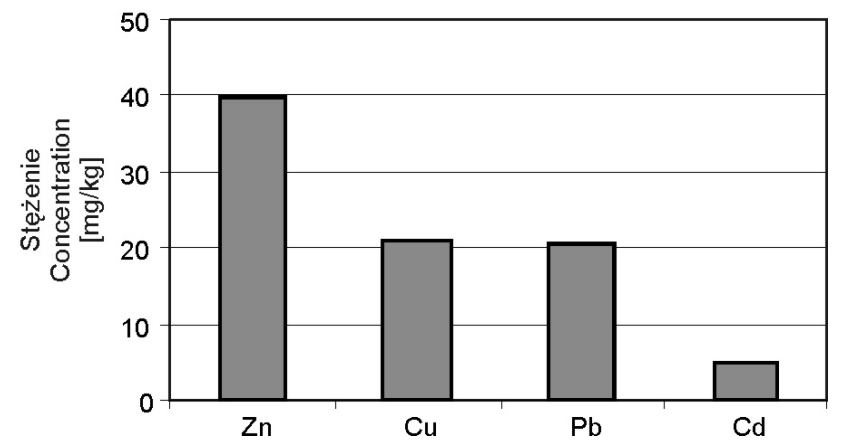

Rys. 5. Metale ciężkie w osadach dennych

Fig. 5. Heavy metals in bottom sediments

W wodach Jeziora Zegrzyńskiego duży udział stanowiły formy bioprzyswajalnych metali $(\mathrm{J}+\mathrm{LK})$. Najsłabiej związany w tej postaci był $\mathrm{Pb}(37 \%)$, najsilniej $\mathrm{Cd}(45 \%)$ i Zn (44\%). Taki rozdział wskazuje na dużą mobilność rozpuszczonych form metali, które mogą powodować toksyczne oddziaływanie na organizmy żywe (rys. 4).

Analiza udziału form rozpuszczonych metali ciężkich w powierzchniowej i naddennej warstwie wody wykazała dość równomierny podział z nieznaczną tendencją wzrostową w naddennej warstwie. Największe różnice w udziale procentowym form rozpuszczonych wykazywał cynk (39\% warstwa powierzchniowa) i kadm (36\% warstwa powierzchniowa).

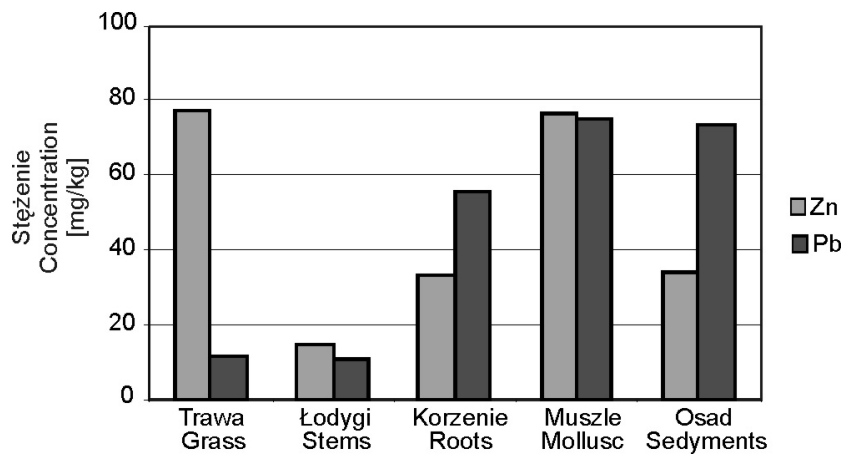

Rys. 6. Cynk i ołów w organicznych i nieorganicznych frakcjach Fig. 6. Zinc and lead in organic and inorganic fractions

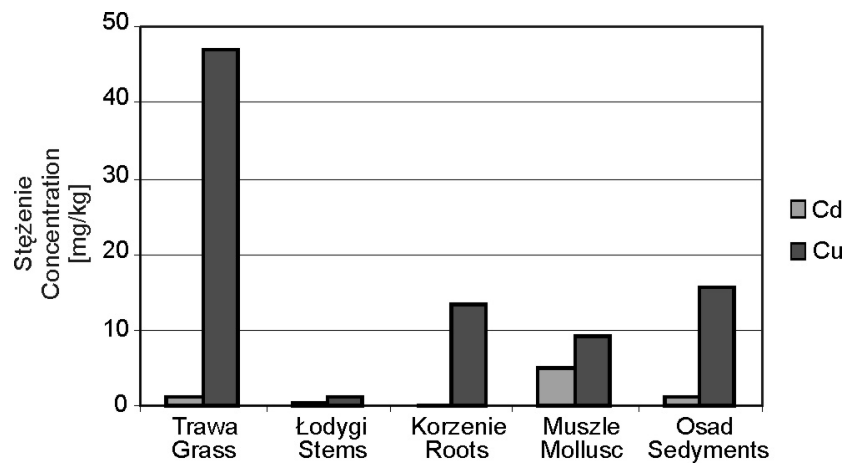

Rys. 7. Miedź i kadm w organicznych i nieorganicznych frakcjach

Fig. 7. Copper and cadmium in organic and inorganic fractions

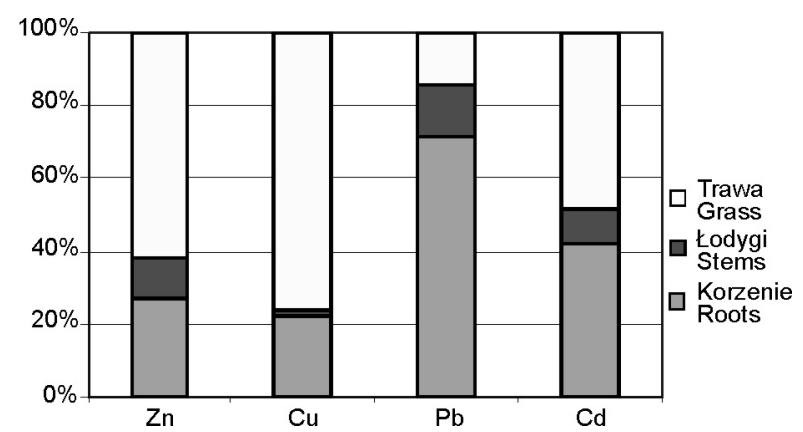

Rys. 8. Procentowy udział metali w częściach roślin

Fig. 8. Participation of proportional metals in parts of plants

Ilość metali związana w zawiesinie, w dwu warstwach wody, była bardziej zróżnicowana (rys. 2). Udział miedzi w górnej warstwie wody był niższy $(27 \%)$ niż w warstwie naddennej. W wodach Jeziora Zegrzyńskiego najsłabiej $\mathrm{z}$ zawiesiną $\mathrm{w}$ dolnej warstwie wody wiązany był ołów (38\%). Wysokie wartości metali zaadsorbowane na cząstkach zawiesiny uzyskano również w badaniach wody rzeki Kłodnicy, rzek śródziemnomorskich i Dunaju (Dassenakis i wsp. 1998; Guieu i wsp. 1998; Davide i wsp. 2003; 
Barbusiński i wsp. 2012). Metale związane w zawiesinie moga być przyswajalne przez organizmy heterotroficzne drogą pokarmową (zooplankton i ryby planktonożerne). Zooplankton i fitoplankton pobierające metale bezpośrednio $\mathrm{z}$ wody często uznawane są za bioindykator zanieczyszczeń wód metalami (Franzin 1984; Marek 1990). Zawiesiny mają silną tendencję do sedymentacji (Jenne 1986) i są skutecznym czynnikiem usuwającym metale ciężkie z wody do osadów dennych. Jak stwierdzono w badaniach wcześniejszych, w wodach Jeziora Zegrzyńskiego $\mathrm{Pb}$ i $\mathrm{Zn}$ silnie wiążą się z koloidalnymi uwodnionymi tlenkami $\mathrm{Fe}$ i Mn (główna postać w wodach powierzchniowych) i mogą być deponowane w osadach dennych (Wojtkowska 1998).

Odłożone metale w osadach dennych stanowią wskaźnik zanieczyszczenia zbiornika. Kumulowane w osadach metale moga być uruchamiane do biomasy w procesach bioakumulacji i bioprzyswajania. Wartości metali, przedstawione na rysunku 5. i w tabeli 4., wskazują na zróżnicowanie ich zawartości w osadach dennych Jeziora Zegrzyńskiego. Uzyskane wartości pozwalają uszeregować metale zgodnie $\mathrm{z}$ rosnącą aktywnością osadów $\mathrm{w}$ ich kumulacji: $\mathrm{Zn}>\mathrm{Cu}>\mathrm{Pb}>\mathrm{Cd}$. Taki układ koreluje $\mathrm{z}$ udziałem metali $\mathrm{w}$ zawiesinie, co potwierdza znaczenie zawiesin $\mathrm{w}$ usuwaniu metali $\mathrm{z}$ wody do osadów dennych. Zawartości metali w osadach Jeziora Zegrzyńskiego były wyższe niż w innych zbiornikach zaporowych Polski, o silniejszej antropopresji (Jancewicz i wsp. 2012). Podobnie, jak wykazali inni autorzy (Barbusiński i Nicoń 2011; Jancewicz i wsp. 2012), istotnym problemem jest zanieczyszczenie osadów dennych Jeziora Zegrzyńskiego kadmem.

Wpływ roślinności: skrzypu bagiennego (E. fluviatile), oczeretu jeziornego (S. lacustris), manny jadalnej (G. fluitans), pałki wąskolistnej (T. angustifolia) i szerokolistnej (T. latifolia), jeżogłówki gałęzistej (S. erectum) na biogeochemię metali śladowych zaznaczał się w analizie stężenia $\mathrm{z}$ podziałem na: korzenie, łodygi i części zielone roślin (rys. 6-8). Badane metale związane były w dużym stopniu w korzeniach i częściach zielonych (tab. 5). Najniższy udział badanych metali stwierdzono w łodygach. W roślinności Jeziora Zegrzyńskiego najsłabiej wiązany był ołów, nieco mocniej kadm i cynk (Cd słabiej niż Zn), natomiast miedź wiązana była w największych ilościach. Uzyskane wyniki wskazują na silną kumulację metali w częściach nadziemnych roślin.

Analizie poddano również mięczaki, z gatunku małż szczeżuja pospolita (A. anatina), pobrane razem z osadami dennymi. Udział metali ciężkich w mięczakach, korzeniach i osadach dennych był zróżnicowany (tab. 5). Najwyższą ilość cynku, ołowiu i kadmu stwierdzono w muszlach małż. Miedź najsilniej kumulowana była w częściach zielonych roślin. W osadach oraz korzeniach cynk i miedź występowały na podobnym poziomie. Jak przedstawia rysunek 8 . w roślinach najsilniejsza akumulacja kadmu zachodziła w częściach zielonych. Bardzo wysoką zdolność akumulacji wykazywała ta część rośliny w stosunku do miedzi i cynku.

Taki rozdział metali w biomasie świadczy o znacznej aktywności metali zdeponowanych w osadach dennych. Labilnie związane metale ciężkie w osadach (formy: jonowowymienna i węglanowa) (Wojtkowska i Bogacki
2012), mogą ulegać pobieraniu przez system korzeniowy roślin i migrować do części zielonych. Mniej aktywne formy związane $\mathrm{w}$ osadach $\mathrm{z}$ frakcją organiczną oraz tlenkami Fe i Mn również mogą ulegać bioprzyswajaniu. Proces ten będzie zależał od warunków panujących przy dnie zbiornika i w powierzchniowej warstwie osadów dennych. W wodach Jeziora Zegrzyńskiego, przy średniej głębokości około $4 \mathrm{~m}$, nie występuje stratyfikacja termiczna i tlenowa, a mieszanie mas wody zachodzi w całej objętości zbiornika. Warunki dobrego natlenienia sprzyjają wiązaniu metali w charakterystycznych dla nich frakcjach w osadach dennych (miedzi w organicznej, cynku z uwodnionymi tlenkami Fe i Mn, ołowiu w krystalicznej i organicznej, kadmu w jonowowymiennej i węglanowej) (Wojtkowska 2013).

Zróżnicowanie zawartości metali ciężkich w korzeniach, pędach, liściach lub organach reprodukcyjnych jest cechą gatunkową. Zależy od ruchliwości (przemieszczanie z korzeni do pędu) toksycznych jonów. Ruchliwość metali $\mathrm{W}$ roślinach pobranych z Jeziora Zegrzyńskiego [skrzyp bagienny (E. fluviatile), oczeret jeziorny ( $S$. lacustris), manna jadalna ( $G$. fluitans), pałki wąskolistne (T. angustifolia) i szerokolistne (T. latifolia), jeżogłówka gałęzista $(S$. erectum)] zmieniała się zgodnie z szeregiem: $\mathrm{Cd}>\mathrm{Zn}>\mathrm{Ni}$ $>\mathrm{Cu}>\mathrm{Pb}$ (Chen i wsp. 1997). Metale ciężkie indukują w roślinach syntezę bogatych w reszty tiolowe polimerów. Po związaniu metalu kompleks przemieszcza się do wakuoli i tam może zachodzić reakcja z kwasami organicznymi, pochodnymi fenoli i glikozydami. Proces ten zatrzymuje związane metale w korzeniu, co zapobiega przedostawaniu się ich do pędów („detoksyfikuje” część nadziemną) (Chen i wsp. 1997; Harada i wsp. 2001).

Główną drogę powrotu metali do środowiska stanowi rozkład obumierających roślin. Niektóre metale szybko uwalniane są $\mathrm{z}$ biomasy $(\mathrm{Mn})$, niektóre zostają związane w powstającym detrytusie $(\mathrm{Cu}, \mathrm{Cr})$, który stanowi silne podłoże adsorpcji metali. Roślinność szuwarowa wykazuje mechanizm pobierania nadmiernej ilości metali ciężkich i zawartość ich w tych roślinach może przekraczać wielokrotnie wartości obserwowane w otaczającym środowisku (osady). Gatunki roślin i zwierząt wykazujące zróżnicowaną wrażliwość i charakterystyczną reakcję na działanie toksycznych metali w środowisku nazywane są bioindykatorami, biowskaźnikami, wskaźnikami biologicznymi, jak również organizmami wskaźnikowymi (Nałęcz-Jawecki 2003; Wardencki 2004; Rabajczyk i wsp. 2008). Duża produkcja biomasy tych roślin oraz silna kumulacja składników środowiska wodnego, w tym metali ciężkich, wpływa na poprawę jakości wód powierzchniowych (Romanowska 2002; Czamara i Czamara 2008).

\section{Wnioski / Conclusions}

1. Przeprowadzone badania wskazują na znaczne zanieczyszczenie środowiska Jeziora Zegrzyńskiego metalami ciężkimi.

2. Analizowane metale najsilniej wiązały się $\mathrm{z}$ fazą stałą zawiesiną i osadami dennymi, stężenia form rozpuszczonych były niskie. Wskazuje to na duże znaczenie 
zawiesiny $\mathrm{w}$ transporcie metali ciężkich zarówno w toni wodnej, jak i w biocenozie zbiornika.

3. Przeprowadzone badania wykazały akumulację metali w roślinności nadbrzeżnej - miedź i cynk kumulowane były głównie $\mathrm{w}$ częściach zielonych roślin, natomiast kadm i ołów w korzeniach.

4. Uzyskane wyniki badań wskazują na istnienie silnych współzależności między stężeniem badanych metali w osadach dennych a ich stężeniami w roślinności nadbrzeżnej i mięczakach.

5. Analiza zawartości metali w muszlach badanych mięczaków wykazała silną kumulację w nich cynku i ołowiu. Zarówno muszle, jak i badana roślinność wodna mogą stanowić bioindykatory zanieczyszczenia metalami ciężkimi Jeziora Zegrzyńskiego.

\section{Literatura / References}

Barbusiński K., Nocoń W. 2011. Zawartość związków metali ciężkich w osadach dennych Kłodnicy. Ochrona Środowiska 33 (1): $13-17$.

Barbusiński K., Nocoń W., Nocoń K., Kernert J. 2012. Rola zawiesin w transporcie metali ciężkich w wodach powierzchniowych na przykładzie Kłodnicy. Ochrona Środowiska 34 (2): 33-38.

Chen J., Zhou J., Goldsbrough P.B. 1997. Characterization of phytochelatin synthase from tomato. Physiol. Plant. 101: $165-172$.

Czamara A., Czamara W. 2008. Metale ciężkie w systemie ekologicznym zbiornika Mściwojów. Infrastruktura i Ekologia Terenów Wiejskich, PAN 9: 283-296.

Dassenakis M., Scoullos M., Foufa E., Krasakopoulou E., Pavlidou A., Kloukinioutou M. 1998. Effects of multiple sources pollution on a small Mediterranean river. Appl. Geochem. 13: 197-211.

Davide V., Pardos M., Diserens J., Ugazio G., Thomas R., Dominik J. 2003. Characterisation of bed sediments and suspension of the river Po (Italy) during normal and high flow conditions. Water Res. 37: 2847-2864.

Fang T., Li X.D., Zhang G. 2005. Acid volatile sulfide and simultaneously extracted metals in the sediment cores of the Pearl River Estuary, South China. Ecotoxicol. Environ. Safety. 61: 420-431.

Franzin W.G. 1984. Aquatic contamination in the vicinity of the base metal smelter ta Flin Flon, Manitoba, Canada - A case history. p. 523-550. In: "Environmental Impacts of Smelters" (J.O. Nriagu, ed.). Wiley Interscience, New York, 583 pp.

Głosińska G., Siepak J. 2006. Metale ciężkie w obszarze równin zalewowych. Ekologia 3 (35): 36-39.

Guieu C., Martin J.M., Tankere S.P.C., Mousty F., Trincherini P., Bazot M. 1998. On the trace metal geochemistry in the Danube River and western Black Sea. Estuarine Coastal and Shelf Sci. 47: 471-485.

Harada E., Choi Y.-E., Tsuchisaka A., Obata H., Sano H. 2001. Transgenic tobacco plants expressing a rice cysteine synthase gene are tolerant to toxic levels of cadmium. J. Plant Physiol. 158 (5): 655-661.

Helios-Rybicka E. 1991. Akumulacja i mobilizacja metali ciężkich w osadach środowiska wodnego. s. 18-23. W: Mat. Konf. Geologiczne aspekty ochrony środowiska. AGH, Kraków, 21-23.10.1991, 276 ss.

Jancewicz A., Dmitruk U., Sośnicki Ł., Tomczuk U., Bartczak A. 2012. Wpływ zagospodarowania zlewni na jakość osadów dennych. Ochrona Środowiska 34 (4): 29-34.

Jenne E.A. 1986. Chemical species in freshwater and terrestial system. p. 22-147. In: "The Importance of Chemical "Speciation" in Environmental Process" (M. Bernhard, F.E. Brinckman, P.J. Salder, eds). Springer-Verlag, Berlin, 217 pp.

Kamiński I. 2011. Lokalna Strategia Rozwoju - załącznik nr 1 do uchwały nr 2/11 Walnego Zebrania Członków Związku Stowarzyszeń „Partnerstwo Zalewu Zegrzyńskiego”. Legionowo, 17.03.2011, 103 ss.

Marek J. 1990. Metale ciężkie w środowisku wodnym doliny Baryczy. Ocena zagrożeń gospodarki rybackiej. Wydawnictwo AR, Wrocław, $54 \mathrm{pp}$.

Nałęcz-Jawecki G. 2003. Badanie toksyczności środowiska wodnego metodą bioindykacji. Biul. Wydz. Farm. AMW 2: 11-17.

Rabajczyk A., Jóźwiak M.A. 2008. Możliwości wykorzystania makrofitów jako bioindykatorów metali ciężkich zdeponowanych w osadach dennych. [The possibilities of using macrophytes as bioindicators of heavy metals occurring in sediments]. Monitoring Środowiska Przyrodniczego 9: 19-26.

Romanowska W. 2002. Redukcja związków azotu i fosforu w zbiorniku wstępnym Mściwojów. Wydawnictwo AR, Wrocław, 57 ss.

Steinberg C. 1980. Species of dissolved metal derived from oligotrophic hard water. Water Res. 14: 1239-1250.

Wardencki W. 2004. Bioanalityka w ocenie zanieczyszczeń środowiska. Centrum Doskonalenia Analityki i Monitoringu Środowiska, Gdańsk, 111 ss.

Wojtkowska M. 1998. Metale ciężkie w toni wodnej i osadach dennych Jeziora Zegrzyńskiego. Wydawnictwo Politechniki Krakowskiej: 109-117, 470 ss.

Wojtkowska M. 2000. Obniżenie zawartości metali ciężkich w procesie sedymentacji dla wód Zbiornika Zegrzyńskiego w aspekcie jakości wód ujmowanych przez Wodociag Północny. Chemia i Inżynieria Ekologiczna 7 (3): 283-292.

Wojtkowska M. 2011. Content of selected heavy metals in water and riverbed sediments of the Utrata river. Environ. Prot. Engin. 37 , 3 (13): 55-62.

Wojtkowska M. 2013. Migration and forms of metals in bottom sediments of Czerniakowskie Lake. Bull. Environ. Contamin. Toxicol. 90 (2): $165-169$.

Wojtkowska M., Bogacki J. 2012. Wykorzystanie analizy specjacyjnej w monitoringu metali ciężkich w osadach dennych na przykładzie rzeki Utraty. Ochrona Środowiska 34 (4): 43-46. 